\title{
The Influence of Role Ambiguity and Role Conflict on Employee Creativity at PT. XYZ
}

\author{
Tinjung Desy Nursanti \\ Bina Nusantara University \\ tinjungdesy@yahoo.com \\ Juliano Satria Indra Putra \\ Bina Nusantara University \\ theboyahassan@gmail.com
}

\begin{abstract}
The objectives of this research are to determine the influence of role ambiguity and role conflict on employee creativity either partially or simultaneously. This research used associative method by collecting primary and secondary data obtained through the literature study, interviews, and distributing questionnaires to 30 respondents that happens to be the employee of PT XYZ. Then data is processed using multiple regression method. From the data analysis, it is shown that role ambiguity has a positive and significant influence to employee creativity as much as $36,9 \%$. Another result of this research shows that role conflict doesn't have a significant influence on employee creativity with a value of $7,6 \%$. While another result of this research shows that role ambiguity and role conflict simultaneously had positive influence significantly as much as $40,4 \%$ on employee creativity at PT XYZ.
\end{abstract}

Keywords: role ambiguity, role conflict, employee creativity, multiple regression

\begin{abstract}
Abstrak
Tujuan dari penelitian ini adalah untuk mengetahui pengaruh dari ambiguitas peran dan konflik peran pada kreativitas karyawan baik secara parsial maupun secara simultan di PT XYZ. Penelitian ini menggunakan metode asosiatif dengan menggunakan data primer dan diperoleh melalui studi pustaka, wawancara, dan penyebaran kuesioner kepada 30 responden yang akan diuji pada karyawan PT. XYZ. Data tersebut diolah dengan menggunakan metode regresi berganda. Dari analisis data, terlihat bahwa ambiguitas peran memiliki pengaruh positif dan signifikan terhadap kreativitas karyawan sebesar 36,9\%. Hasil lain dari penelitian ini menunjukkan bahwa konflik peran tidak memiliki dampak yang signifikan terhadap kreativitas karyawan dengan nilai 7,6\%. Sedangkan hasil lain dari penelitian ini menunjukkan bahwa ketidakjelasan peran atau ambiguitas peran serta peran konflik secara bersamaan memiliki pengaruh positif secara signifikan sebesar 40,4\% pada PT XYZ.
\end{abstract}

Kata Kunci: role ambiguity, role conflict, employee creativity, regresi berganda

\section{Introduction}

A great company is a company that could equally managed their human resource in order to work harmoniously and be able to run their business as planned and reach its goals and objectives. Employees are the most valuable asset in an organization because they might act as a 'spearhead' that runs the entire task and responsibility in the company. Those become particular reason why a proper human resource management is needed.

Managing employees as well as guiding them to do their best in order to achieve the company goals had already been a major problem for manager. Finding out the most effective and efficient ways to manage the employees are vital because managing employees itself isn't as easy as telling people what to do and making people do things upon the managers command needs to be done systematically. Employees had been rolling in and out of the organization. Making them to stay at that organization could be a difficult stuff for the manager as well as making the employee satisfied with the incentive given from the organization is a must in terms of an effort to making them feel satisfied. Meanwhile giving the employees security upon their jobs and personal life needs are an important issue for the organization. Therefore, in order to work at their best, employee needs to know their job description as it is the purpose and a mandatory view of the existence of employees in organization.

PT XYZ is an organization that was established on 8 April 1988 by Mrs. Poerbaningsih Adi Warsito S.H. with the stocks owned by Yayasan Kesejahteraan Bumi Daya and Retirement program funds of Bank Mandiri Indonesia. PT XYZ has its core business in building service supplier and taking sectors on car rentals, construction 
service and building rental service. The company vision is to provide a good quality and affordable service upon its competitor. To find out about the problem in PT XYZ, the interview with Mr. Sihansyah Riyadi as one of the board of comissioner of PT XYZ was held.

The information given was trying to figure out about the phenomenon of existing role ambiguity and role conflict in the organization. It seemed like that PT XYZ has not implemented the role clarity as the opposite of role ambiguity to their employees, therefore sometimes it triggered the role conflict among the employees of the organization. This company is a perfect example that can be used in this research due to the small number of employees, 30 employees exactly, whereas role conflict and role ambiguity exists in order to cope with day to day demands of the organizational operation. With this curiosity, this research would like to examine whether those variables would affect the creativity of the employee on PT XYZ so that the organization could avoid future problem that are related to the topic of this research.

This research will be discussing and mainly focusing on the influence of role ambiguity and role conflict on employee creativity of the employee at PT XYZ. Therefore, based on the problem background and the facts above, the research questions can be defined as follows:

1. Is there an influence of role ambiguity (X1) on employee creativity (Y)?

2. Is there an influence of role conflict (X2) on employee creativity $(\mathrm{Y})$ ?

3. Is there an influence of role ambiguity (X1) and role conflict (X2) simultaniously on employee creativity $(\mathrm{Y})$ ?

\section{Theoretical Framework}

Firth-Cozen (2001) stated that role ambiguity is the opposite of role clarity and increases the incidence of adverse outcomes for patients (on Brunetto, Farr-Wharton, and Shacklock, 2011). Role clarity is facilitated by an effective supervisor-subordinate relationship and a perception of satisfaction with the quality of teamwork.

On previous study according to Amabile (1988); Burnside (1990); Shalley (1995) in Tang \& Chang (2010) it could be widely recognized, that enhancing employee creativity is essential for a competitive edge and organizational survival. These researchers identified that several work environment factor could either enhance or reduce the intrinsic motivation of employees, hence increasing or decreasing their creativity. A clear example would be, time pressure or tight deadlines may either benefit or harm employee creativity according to Andrews and Farris (1972); Ekvall and Ryhammer, (1999); Baer and Oldham, (2006); Amabile et al., (1996) in Tang \& Chang (2010).

Role conflict is an important influence to work-related functions of employees. It may occur if expected and perceived roles differs from one and another. In previous decades, many organizations have switched their focus to organizational change, flexibility, and employee empowerment. However, the growing emphasis on organizational change, flexible work arrangements, employee empowerment, and autonomous working conditions have led to a constantly changing job specifications and role uncertainty. Moreover, losing stable job boundaries subsequently increases the potential for role stress according to Applebaum and Berg (1997); Cooper and Dewe (2004) in Tang \& Chang (2010).

The generally accepted concept of role ambiguity according to Breaugh \& Colihan (2004) in Gregson and Wendell (2010) is that role ambiguity occurs when individuals lack a clear definition of their role expectations. Role ambiguity could also be defined as the lack of requirements/ methods to complete their job tasks according to Rizzo, House, \& Lirtzman (1970) in Gregson and Wendell (2010). Employees may encounter role ambiguity for a variety of reasons. The employees are frequently entering situations where there is no possibility for complete information, therefore, it is difficult to receive clear instruction, or apply training received to a specific situation. This lack of information may raise the uncertainty regarding expectations associated with the role according to Gupta \& Jenkins (1985); Lewis \& Cooper (1988) in Gregson and Wendell (2010). With the lack of a clear definition as noted above, for the purpose of this paper, role ambiguity will be defined as the ambiguity on the job that occurs due to lack of clear role expectations, requirements, methods, and information in situational experiences.

According to another theory, the role theory, role ambiguity could be defined as the lack of specificity and predictability for an employee's job or role functions and responsibility according to Kahn et al. (1964); Beehr (1976) in Tang and Chang (2010). Role ambiguity can be a result of poor job descriptions, vague instruction from a supervisor, or unclear cues from co-workers. The result of role ambiguity is cluelessness upon the job and thus be a significant source of other unwanted result such as stress according to Griffin and Moordhead (2009,p173). Unclear role-related information may lead to role ambiguity. Goals are an important factor in creativity because they are often ambiguous, and ambiguity may induce stress. Moreover, Tang and Chang (2010) suggested that employees who are confused by other goals who are attempting to cope with strain or to reduce strain may abandon creative initiatives. Therefore management must establish clear organizational goals to achieve high creativity.

According to Gregson and Wendell (2010) the dimension of role ambiguity are (1) predictability of the outcome or responses to one's behavior which means that employee must be able to predict the outcome of their work and (2) The existence of clarity which means that employee must be aware of what to do and how to do their task on the organization.

Rahim (2011) stated that conflict is inevitable among humans, it is a natural outcome of human interactions that begins when two or more social entities come in con- 
tact with one another in attaining their objectives. While, role conflict is defined as the incompatibility of requirements and expectations from the role, where compatibility is judged based on a set of conditions that influence role performance according to Rizzo, House, \& Lirtzman (1970) in Glissmeyer, Bishop, \& Fass (2010). Role conflict is more intense in jobs where more abstract thinking and decision-making are required according to Menon \& Aknilesh (1994) in Glissmeyer, Bishop, \& Fass (2010).

Role conflict arises as a result of the role expectations of one sender conflicting with the expectations of one or more role senders. Role conflict has also been defined as the extent to which a person experiences pressures within one role that are incompatible with pressures that arise within another role according to Kopelman, Greenhaus, \& Connolly (1983) in Glissmeyer, Bishop, \& Fass (2010). This research will use the theory from Rizzo, House, \& Lirtzman (1970) in Glissmeyer. Role conflict also can be defined as the incompatibility of requirements and expectations from the role.

The present study will more precisely conceptualise role conflict on the basis of two distinct types. Inter-role conflict entails a conflict where the individual perceives others as being responsible for the incompatibility, which might occur when an individual has to perform roles that require incompatible behaviour or when there are conflicting organisational expectations and demands according to Schwab, Iwanicki, \& Pierson (1983) in Glissmeyer, Bishop, \& Fass (2010). In contrast, intra-Role Conflict entails a conflict where the individual perceives $\mathrm{him} /$ herself as being responsible for the incompatibility as occurs when officers have to violate personal values or standards or when officers perceive their role as being beyond their capabilities, time constraints, or available resources according to Schwab, Iwanicki, \& Pierson (1983) in Glissmeyer, Bishop, \& Fass (2010).

This study will examine role ambiguity which is the extent that an individual is uncertain about their duties, authority, and allocation of time, as based on unclear guidelines, directives, and policies. On the basis of this conceptualisation, a number of hypothesises are conceivable. Firstly, it is likely that officers who prefer to perform the role of welfare worker or punitive officer will experience inter-role conflict. This is because officers who are certain about how they should appropriately perform their role are likely to externalise blame for any conflict that they experience. Role Ambiguity is not elaborately defined in the literature. The definition used here is in terms of he predictability of the outcome or responses to one's behavior and the existence or clarity.

According to Gregson and Wendell (2010), role conflict's dimensions are (1) Conflict between the focal person's internal standards or values and the defined role behavior. This is a person-role confiict or intrarole confiict of the focal person as he fills a single position or role (2) Conflict between the time, resources, or capabilities of the focal person and defined role behavior. Where one other person in a related role generates the ineompatibility, this may be viewed as intrasender eonfiict. It may also be organizationally generated. From the point of view of the focal person, there is intrarole confiict or person-Role Conflict such as insufficient capability. (3) Conflict between several roles for the same person which require different or incompatible behaviors, or changes in behavior as a function of the situation such as role overload.

This is inter Role Conflict for the focal person as he fills more than one position in the role system (4) Conflicting expectations and organizational demands in the form of incompatible policies, conflicting requests from others, and incompatible standards of evaluation. These Role Conflict items suggest sanctions attached to role behavior and are therefore related to the Role Ambiguity components which involve the prediction of the outcome of one's behavior. Also, the items may reflect more than the category cited. Finally, the sources of conflict cited in the literatin multiple authority, professional values are for the most part not specifically included in the items.

Creativity is generally defined as the production of ideas that are new and useful according to Shalley et al. (2004) in Ng and Feldman (2012). This research need to rely on self-ratings of creativity because employees themselves are more likely to be aware of the subtleties of their suggestions that make their ideas creative. Indeed, several researchers have argued that creativity usually begins in an "awareness" stage during which individuals both recognize an opportunity to be creative and formulate a potential innovation according to Ong et al. (2003) in Ng and Feldman (2012).

Furthermore, employees may be better able than supervisors and peers to judge the extent to which new ideas are fundamentally or incrementally creative within the work context. Second, it has been frequently argued that being creative is a type of discretionary behavior whose purpose is to benefit the organization based on a study by Axtell et al. (2000) in Ng and Feldman (2012). Employees themselves may be in the best position to assess the intensity or frequency of these intended behaviors on their own. Interestingly, Janssen (2000) in Ng and Feldman (2012) stated that colleagues may not notice an employee's creative contributions unless the employee simultaneously engages in impression management tactics aimed at gaining supervisors and coworkers approval. Third, novel ideas may upset the status quo in some way or put stress on existing interpersonal relationships. As a result, employees may feel reluctant to present their ideas to superiors and peers, especially if they perceive superiors and peers may not share their enthusiasm. For that reason, employees may pitch suggestions to other colleagues or other senior members of the organization in order to get validation and support for their ideas. Mainemelis (2010) stated in Ng and Feldman (2012) refers to this phenomenon as creative deviance.

Thus, it can be argued that self-ratings of creativity are better able to capture those contributions intentionally hidden from supervisors and coworkers. Finally, there are numerous occasions when peer ratings and supervisor ratings of employees' creativity cannot be obtained. For example, there may be cases where either (a) anonymity and confidentiality cannot be assured to respondents or (b) trust in assurances of anonymity and confidentiality 
is not high.

\section{Research Methods}

This research type is associative - causal research. While the aims of this study are to determine the relationship between two or more variables and to determine whether there are influences among others. The unit analysis of this study is the employees of PT XYZ which become the respondents of the questionnaires. While the time horizon used in this study is cross-sectional, which means that the data is retrieved only once, at a certain period.

The data will be used in this research is quantitative, whereas the primary data obtained through a questionnaire using 1-5 Likert scale given to the respondents, which happens to be all of the population of the employees at PT XYZ. This research also uses secondary data from journals and also text books.

Population consist of subject that has spesific characteristic and have equal opportunity to be chosen as sample, therefore this is a population research. According to Sugiyono (2006) the number of minimum respondents that can be used in multiple regression method is 30 , thus means that the number of employee of PT XYZ is sufficient to be furtherly calculated. Riduwan and Kuncoro (2013) also argues that when the subject of study is less than 100 respondents, it is better to take all of the population of the respondents.

The analysis phase in this study begins with the research instrument, by collecting and processing data obtained from the questionnaire by providing the weight of each statement based on the Likert scale, perform validity test and reliability test, perform the classical assumption test, and finally perfom the correlation and regression test. Regression test used is the simple regression and multiple regression test. In practice, the data are processed with the help of a computer by using SPSS (Statistical Product and Service Solutions) version 20.

\section{Results and Discussions}

Through regression analysis performed on PT XYZ, the acquired results are: (1) The correlation between role ambiguity and employee creativity is 0,607 . Thus, the correlation is strong and one way. (2) The correlation between role ambiguity and employee creativity is 0,277 . Thus, the correlation is weak and one way.

Through regression analysis performed on PT XYZ, the acquired results are: (1) Role ambiguity $\left(\mathrm{X}_{1}\right)$ has a positive and significant influence to employee creativity (Y) as much as 0,369 or $36,9 \%$. (2) Role conflict $\left(\mathrm{X}_{2}\right)$ doesn't have a significant influence on employee creativity (Y) with a value of 0,076 or 7,6\%. (3) Role ambiguity $\left(\mathrm{X}_{1}\right)$ and role conflict $\left(\mathrm{X}_{2}\right)$ simultaneously had a positive influence significantly as much as 0,404 or $40,4 \%$ on employee creativity

Based on the research results above, it can be con- cluded that there is a significant influence between role ambiguity and employee creativity on the employees of PT XYZ. According to Sherman in Tang and Chang (2010) "role clarity is a positive motivator for engineers and technical personnel". According to that study, when motivated properly, engineers tend to solve problems that require a high level of effort and innovation to complete a project. Role clarity, one of the dimension of role ambiguity refers to how clearly a set of activities expected from an individual are expressed and that role ambiguity is the reverse situation.

This implies that role ambiguity negatively and significantly affects employee creativity according to Tang and Chang (2010). But on this research, the result is that role ambiguity has a positive influence on employee creativity, this is due to the difference in types of organization that's being researched. In ideal state, the conclusion is that PT XYZ should avoid role ambiguity in order to avoid any role related conflict and the organization should find another way to stimulate and increase their employee creativity. Things like communication plays a big role in order to give a clear directions, information about a specific job, or even communicating about the goals and procedures in the organization. The manager must be one who acts as the informator and delivers the content of the information cleraly to the employees.

Based on the conclusion above, it can be concluded that there is no significant influence between role conflict and employee creativity on PT XYZ. The amount of influence is only at 7,6\% meaning that role conflict is not a contributing factor that affects employee of PT XYZ's employees. The rest $92,4 \%$ is affected by self-efficacy that mediates the relationship between role conflict and creativity and which was not further examined in this research. Another reason behind the insignificant amount of influence is due to the fact that this research is using a population of small company that only consists of 30 people, so the data may vary accross numbers of population. Although there is no significant influence, the organization needs to avoid role conflict by giving its employee a clear job description across divisions so that they don't have to do tasks that are incompatible or diverge from their current job description, to avoid any problems emerging in the future. Explanations that previously have been shown can be interpreted with the following figure 1.

\section{Conclusions and Recommendations}

From this research, it could be concluded that: (1) role ambiguity $\left(\mathrm{X}_{1}\right)$ has a positive and significant influence to employee creativity (Y) at PT XYZ. (2) Role conflict $\left(\mathrm{X}_{2}\right)$ doesn't has a significant influence on employee creativity (Y) at PT XYZ. (3) Role ambiguity $\left(\mathrm{X}_{1}\right)$ and role conflict $\left(\mathrm{X}_{2}\right)$ simultaneously had a positive and significant effect on employee creativity (Y) at PT XYZ.

Based on the conclusions and results of the questionnaire statement item that has the lowest and highest values, the suggestions for PT XYZ are: 


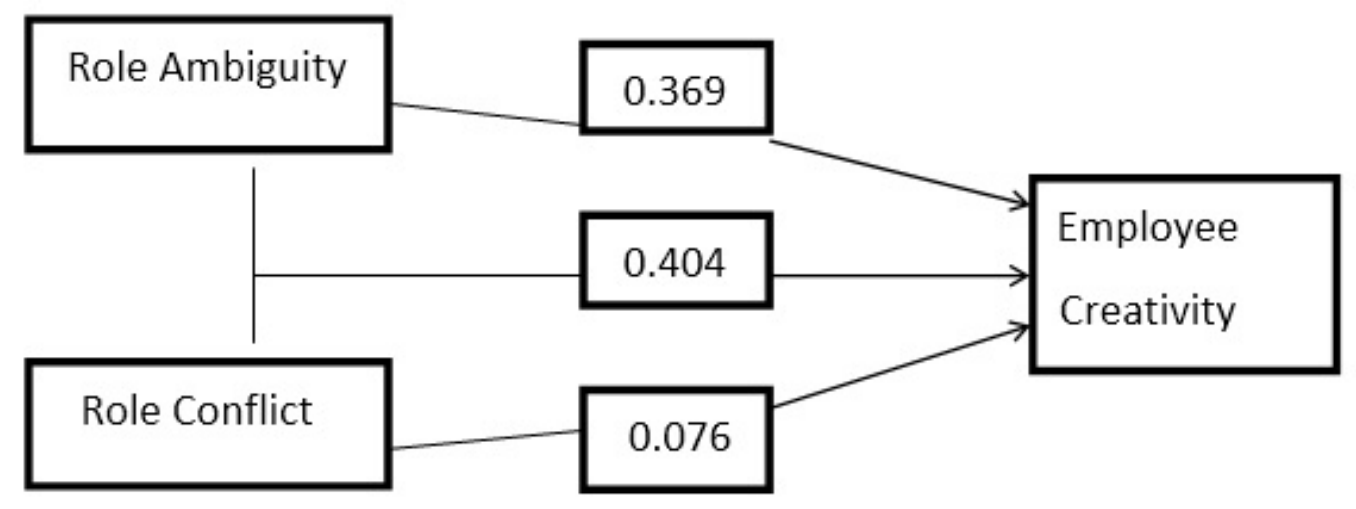

Figure 1. The influence of $X_{1}$ and $X_{2}$ to $Y$

to the constructed questionnaire, the employee of certain about the linkage of their job and that job linkage uncertainty about their job in the organization is non-existence. Also, most of the employee of PT XYZ have a clear planned objectives for their jobs. Thus means that PT $\mathrm{XYZ}$ is recommended to maintain the job clarity which means that the level of role ambiguity in the organization is low to non existence.

To maintain this ideal state, the organization must construct a clear job description and also provide employees with clear information and communication channel in order for the employees to know what to do and not to do in the organization. Developing a bold set of rules and policy is also recommended so that the employees are guided to help PT XYZ achieve its objectives. For further reference, the book of Milner and Palmer (2003) stated that to avoid role ambiguity, management need to ensure that their staff are made explicitly aware of what they are supposed to do and whom they should report to. The organization must also need to engage employee training and personnel development, by doing so this will emphasize tolerance of ambiguity and uncertainty.

(2) Most of employee of PT XYZ don't have to bend/ buck the rule or policy in order to carry out an assignment, thus means that conflicting expectation and organizational demands in the form of incompatible policy is non-existence. Also, the employees are performing their task that suits their values whereas this means that there is no conflict between the focal person's internal standards or values and the defined role behaviour. In order to maintain this ideal state, the organization must avoid giving a task or directions that are incompatible with the values of the majority of its employee. PT XYZ must also encourage their employee to be professionally capable, meaning that its employees should be able to work with different scenarios of problem without having to change their current values.

(3) most of the employee dissagree whether that they are a good source of creative ideas, whereas this means that the organization must develop a way to stimulate the creativity of its employee, one of the solution is to generate a "stimulant" of challenging work place and also task that will make the employee motivated and find creative ways of solving that challenge as well as completing their goals. Also, most of the employee of PT XYZ agrees that they are keep searching out new technologies, techniques, processes, and product ideas and constantly improving PT XYZ to make it run more effective and efficient, which is a great way of constantly improving the organization itself and also creating a creatively derived work situation.

For the next researcher, the suggestions are: (1) Examines other factors that affects or stimulate employee creativity. (2) Expected to develop this research by adding more variable that affects employee creativity.

\section{References}

Brunetto Y., Farr-Wharton R., and Shacklock K. (2011). Supervisor-Nurse Relationships, Teamwork, Role Ambiguity and Wellbeing: Public Versus Private Sector Nurses.

Glissmeyer, M., Bishop J. W., Fass, R. D. (2010). Role Conflict, Role Ambiguity, and Intention to Quit The Organization. The Case of Law Enforcement Officers. 458-469.

Gregson, T. \& Wendell, J. (2010). Role Conflict, Role Ambiguity, job satisfaction and the Moderating Effect of Job-Related Self-Esteem: A latent Variable Analysis. Journal of Applied Bussiness Research, (10) 2, 106-113

Griffin R. \& Moorhead G. (2009). Organizational Behavior: Managing People and Organizations.

Keller, R. T. (1975). Role Conflict and ambiguity: Correlates with job satisfaction and values. Personnel Psychology (28), 57-64.

Kuncoro A., Engkos, and Ridwan. (2008). Path Analysis, Second Edition. Bandung: Alphabeta.

Milner P. \& Palmer S. (2003). Integrative Stress Counselling: A Humanistic Problem-Focused Approach. Great Brittain: Athenaeum Press Ltd., Gateshead, Tyne \& Wear

Ng, T. W. \& Feldman, D. C. (2012). A comparison of selfratings and non-self-report measures of Employee Creativity. Human Relations, (65) 1021-1046. doi: 10.1177/0018726712446015 
Rahim, M.A.(2011). Managing Conflictin Organizations, 4th Edition. 1-72.

Rizzo, J. R., House, R. J. \& Lirtzman, S. I. (1970). Role Conflict and ambiguity in complex organization. Administrative Science Quarterly, 150-163.

Schultz, D. P., Schultz, S. P. Psychology and work today: An introduction to industrial and organizational psycholog, Ninth Edition.

Sugiyono. (2006). Statistika Untuk Penelitian, Seventh Edition. Bandung: Alphabeta.

Tang, Y. T. \& Chang, C. H. (2010). Influence of Role Ambiguity and Role Conflict on Employee Creativity. African Journal of Business Management, 4 (6), 869881. Retrieved from: http://www.academicjournals. org/AJBM

Umar, Husein. (2003). Metode Riset Komunikasi Organisasi. Jakarta: PT Gramedia Pustaka Utama 